\title{
Short-scale temporal variability of physical, biological and biogeochemical processes in the NW Mediterranean Sea: an introduction
}

\author{
V. Andersen ${ }^{1}$, M. Goutx ${ }^{2}$, L. Prieur ${ }^{1}$, and J. R. Dolan ${ }^{1}$ \\ ${ }^{1}$ Université Pierre et Marie Curie-Paris6, INSU-CNRS, Laboratoire d'Océanographie de Villefranche-sur-Mer, 06230 \\ Villefranche-sur-Mer, France \\ ${ }^{2}$ Laboratoire de Microbiologie, Géochimie et Ecologie Marine, Université de la Mediterranée, Centre d'Océanologie de \\ Marseille, CNRS UMR 6117, Campus de Luminy, case 901, 13288 Marseille, France
}

Received: 21 October 2008 - Published in Biogeosciences Discuss.: 23 December 2008

Revised: 6 March 2009 - Accepted: 11 March 2009 - Published: 18 March 2009

\begin{abstract}
In the framework of the PROOF-PECHE project (http://www.obs-vlfr.fr/proof/vt/op/ec/peche/pec.htm) a multi-disciplinary team performed experiments and collected samples during the DYNAPROC2 cruise aboard the RV Thalassa from September to October in 2004. The cruise provided data on the functioning of the pelagic food web by sampling over a month long period in the NW Mediterranean Sea at a fixed station subject to weak horizontal advection currents during a period of hydrological stability. This paper describes the background of the cruise and provides an overview of the results derived from the campaign which constitute the special section. The major objective of the cruise was to assess the relative importance and variability of the pathways of carbon in the open ocean. Intensive sampling through 4 periods of 5 days each was accomplished at a site near the DYFAMED time-series site. The site was near stable in terms of hydrodynamics as there was some evidence of an intrusion of low-salinity coastal water. The cruise yielded a comprehensive data set acquired by sampling over a vertical spatial dimension $(0-1000 \mathrm{~m})$ and at high frequencies (ranging from every $3,6,12$ and/or $24 \mathrm{~h}$ ), unique for the summer to autumn transition in the North Western Mediterranean. Parameters investigated included the biochemical composition of dissolved organic matter (lipids), and the structure of bacterial communities, phytoplankton and zooplankton community compositions and abundances, as well as zooplankton metabolism, and particulate organic carbon fluxes. Nearly all the parameters described in this section, as well as reports appearing elsewhere, showed time-course variabilities of
\end{abstract}

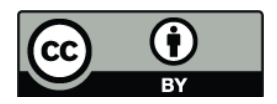

Correspondence to: J. R. Dolan (dolan@obs-vlfr.fr) similar magnitude to those known from a previous study of the spring-summer seasonal transition, a period of marked hydrological change, at the same study site. Remarkably, the least variable characteristic of the system appeared to be the identities of the dominant taxa across several trophic levels (copepods, phytoplankton, ciliates, and bacteria) throughout the study period despite large shifts in stock sizes and fluxes. Thus, the studies of DYNAPROC 2 documented considerable temporal variability of stocks and rates in a system which was, from a hydrological and taxonomic point of view, relatively stable.

\section{Background}

Research efforts in biological oceanography have been concentrated in recent years around two major themes: 1) the responses of biological systems to shifts in forcing factors, especially climatic changes and 2) the interactions between biogeochemical cycles and the structure and function of ecosystems. Advancing within either theme requires knowledge of the variability of the structure and function of pelagic ecosystems. The project PECHE (Production and Export of Carbon: control by HEterotrophic organisms at short temporal scale) and its main operation, the oceanographic campaign DYNAPROC 2, was designed with the specific goal of assessing variability in the pelagic food web and its effect on biogeochemistry, targeting an oligotrophic system, the NW Mediterranean Sea at the end of the summer.

Satellite images clearly show the fact that ocean physics play an essential role in governing the spatial and temporal distribution of phytoplankton on large scales (Garçon et al., 2001). Thus, productive areas correspond with those in

Published by Copernicus Publications on behalf of the European Geosciences Union. 


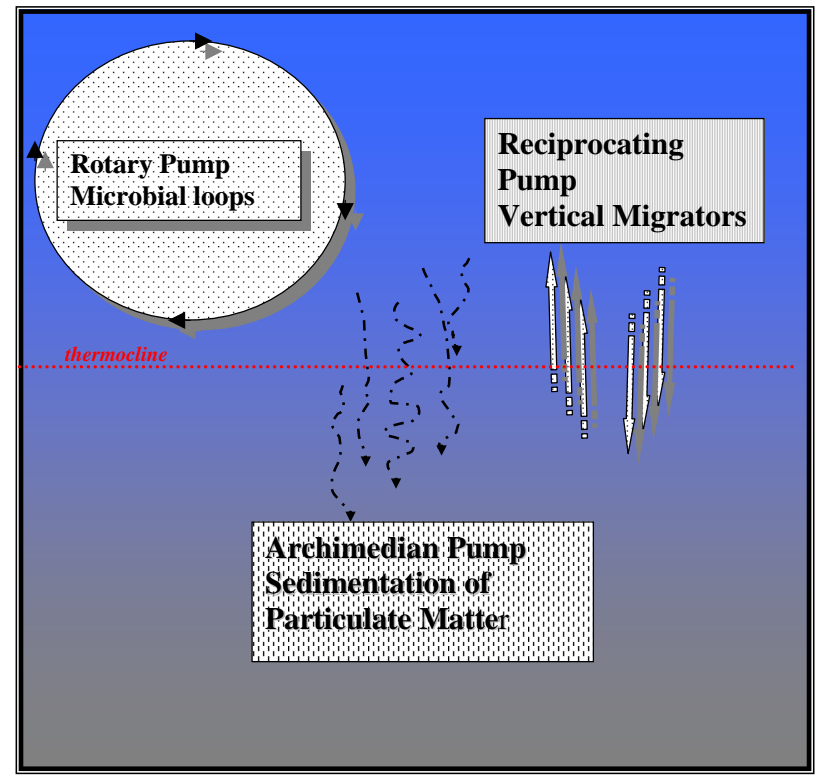

Fig. 1. Schematic representation of the carbon pumps or pathways following Longhurst (1991).

which the euphotic zone is nutrient-rich, for example, from deep water inputs. For phytoplankton, the role of resources (i.e., nutrients) has long been considered as more important than that of predation or grazers. Nonetheless, the possibility that consumers of phytoplankton could play a large role, especially in open ocean systems has been suggested repeatedly (e.g. Banse, 1994, 1995; Verity and Smetacek, 1996). Furthermore, the activity of grazers can affect, directly or indirectly, other components of the plankton food web, for example, bacteria and bacterivores (Christaki and Van Wambeke, 1995; Christaki et al., 1996, 1998; Van Wambeke et al., 1996). Likewise, activities of the terminal trophic levels in food web models often affect components throughout the food web. For example, Steele and Henderson (1992) underlined the importance of the top predators and Frost and Franzen (1992) showed that their model correctly reproduced phytoplankton dynamics only when it included 2 trophic levels of carnivores. Obviously, the functioning of pelagic food webs depends on some equilibrium between resources and predation. While the relative importance of the two remains a subject of debate (e.g., Longhurst, 1991; Banse, 1995; Franks, 2001; Marine Zooplankton Colloquium 2, 2001), there is, regardless, a need to quantify the variability in the activity of grazers on a variety of temporal and spatial scales for a correct portrayal of pelagic food web dynamics.

Further complicating the situation with regard to pelagic food webs is the fact that there are, schematically, two principal carbon flux pathways: "microbial" and "herbivorous". The microbial pathway is mediated by the activities of heterotrophic and autotrophic prokaryotes, viruses, pico and nano-eukaryotes both autotrophic and heterotrophic, ciliates and other heterotrophic protists. The herbivorous pathway traces fluxes through large phytoplankton (typically diatoms and dinoflagellates) and metazoan zooplankton such as copepods, salps, etc. The distinct manners in which the two pathways contribute to the biological $\mathrm{CO}_{2}$ pump can be illustrated by recalling Longhurst's (1991) classification of biological pumps (Fig. 1): 1) Rotary Pump, corresponding to the retention and circulation of matter within the euphotic zone inside microbial loops, 2) Archimedean Pump, representing the vertical flux of particulate matter in the form of phytoplankton aggregates, fecal pellets, marine snow, carcasses, etc. produced by metazoan plankton and phytoplankton in the herbivorous pathway, and finally, 3) Reciprocating Pump reflecting the activities of organisms which migrate vertically in the water column between the deep layers to the surface waters. It is worthwhile reviewing mechanisms and organisms involved in each "pump" to situate the various foci of the multidisciplinary study DYNAPROC 2.

The Rotary Pump rotates around heterotrophic bacteria. They play an essential role assimilating and re-mineralizing particulate and dissolved organic matter. They are unique in their capacity to concentrate and re-package dissolved organic matter and thus release back into solution nutrients essential for primary production. Paradoxically, despite the clear importance of bacterial activities, the precise nature of the relationships between organic matter (concentrations, characteristics) and the composition or activity of bacterioplankton are poorly known and were thus one of the foci of the DYNAPROC 2 project.

The Archimedean Pump (downward flux of particulate organic matter) represents the net activity of a very diverse set of metazoan organisms, in terms not only of taxonomy, but also ecology. For example, size relationships between consumer and prey are very different comparing copepods which feed on diatoms, to appendicularians feeding on bacteria (Longhurst, 1991; Fortier et al., 1994). Different zooplankton taxa produce particulate matter with distinct characteristics of density, ballast content, biochemical composition, and attached bacteria. Knowledge of the community composition of the metazoan zooplankton, and variability in feeding activity, is essential in assessing the effects of their activities and represented another focus of the DYNAPROC 2 cruise campaign. Another source of particulate organic matter can be phytoplankton, either whole senescent cells, or coagulated matter of phytoplanktonic origin. Little is known concerning its temporal variability.

Part of the organic matter produced in the surface layer is transferred to depth not through the sedimentation of nonliving matter but rather through active transport by organisms which migrate through the water column. The Reciprocating Pump is the result of the activities of diel migrators. The possible importance of migrators in terms of carbon flux to deep layers in the ocean, reintroduction of nutrients into the shallow water layers, as well as a structuring element in surface 

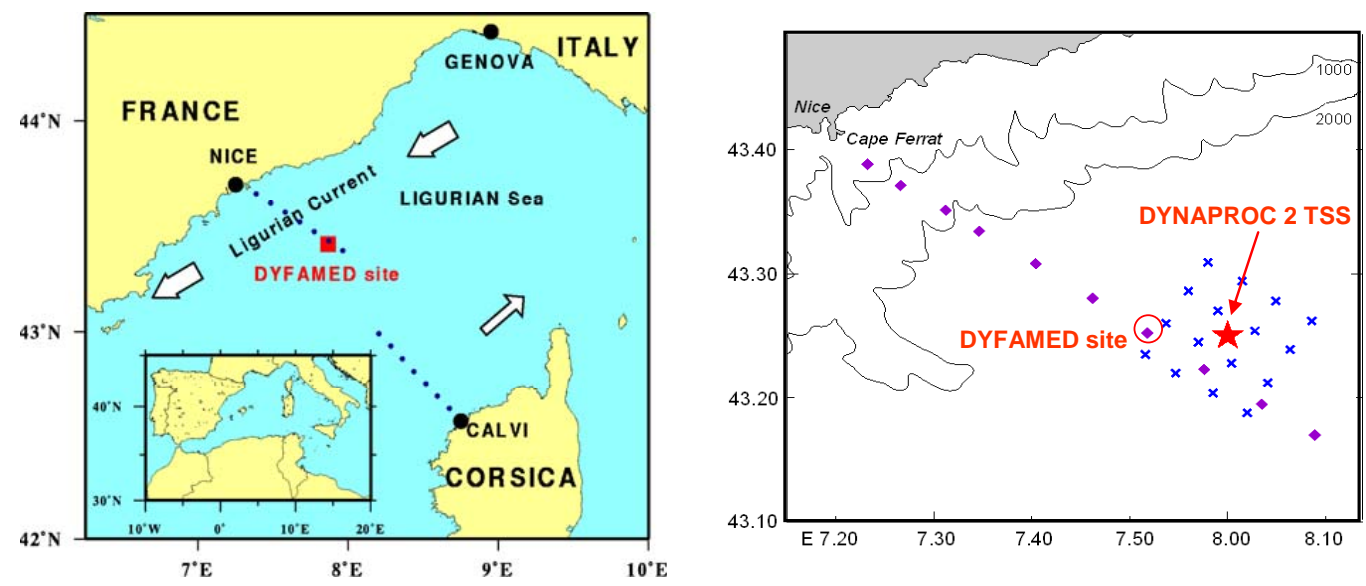

Fig. 2. Location of the time series station (TSS) occupied during the DYNAPROC 2 cruise and the network of survey stations sampled for hydrological data.

layer food webs, while recognized, has been neglected (e.g. Angel, 1989; Longhurst, 1991; Banse, 1995; Marine Zooplankton Colloquium 2, 2001). Assessment of vertical migrators was an important focus for the DYNAPROC 2 study.

High-frequency observations were made during the DYNAPROC 2 study which was relatively stable in hydrology. This permitted some interesting comparisons to be made between the variability encountered and that recorded during a previous multi-disciplinary study carried out during the spring to summer transition in 1995 detailed in Andersen and Prieur, 2000; Christaki et al., 1996; Copin-Montégut, 2000; Goutx et al., 2000; Pérez et al., 1997, 2000; Stemmann et al., 2000; Vidussi et al., 2000; Andersen et al., 2001a, b; Van Wambeke et al., 2001. Below we will first very briefly review the cruise plan then highlight some of the findings described in detail in the individual papers of this special section. In the framework of the PECHE project, two additional shortcruises were conducted at the DYFAMED site in March and June 2003 (Garcia et al., 2006; Ghiglione et al., 2007; Bourguet et al., 2009) whose results are used as spring and early summer reference in several individual papers of this special issue.

\section{Cruise summary and physical context}

The DYNAPROC 2 cruise campaign (Dynamique des Processus Rapide dans le Colonne d'Eau) began the 14 of September and ended the 17 of October aboard the research vessel N/O Thalassa in 2004. The principle observations were made at a Time Series Station (TSS) located at $43^{\circ} 25 \mathrm{~N}, 8^{\circ} \mathrm{E}$ between Nice and the island of Corsica near the Dyfamed Time Series Station (reviewed in Marty 2002) (Fig. 2a). A network of 16 satellite stations was also sampled 3 times to verify horizontal gradients surrounding the TSS central point as weak (Fig. 2b). At the TSS intensive sampling was conducted through 4 cycles of 5 day duration. The cruise was composed of two legs, with sampling at the TSS beginning on 17 to 30 September and resuming on 2 October, continuing until 14 October.

Throughout the sampling periods, the TSS was located beyond the Liguro-Provence front and the Ligurian coastal current. This conclusion was based on: 1) monitoring the temperature and salinity of the mixed layer and the dynamic height calculated for each of 10:00 CTD casts per day, 2) drift of the sediment trap line, and 3) preliminary analysis of the ADCP current data. The system remained stratified throughout the cruise except at the end, when the second wind event induced the mixing of the surface layer (Fig. 3a and b). However, two incidents of an intrusion of low-salinity $(<38.3 \%$ o $)$ water, presumably of coastal origin, were noted. The first one occurred between 21-30 September with low salinity waters found from 15 to $75 \mathrm{~m}$ depth, and the second one from 9 12 October found from 20 to $40 \mathrm{~m}$ depth (see Fig. 3c). The sampling site was characterized by a strong, persistent, thermocline found at about 25 except at the end of the sampling period (11-16 October) when the thermocline was located at $40 \mathrm{~m}$ depth.

\section{Phytoplankton composition and primary production}

Organic carbon circulating in the biological pump (either Rotary, the Archimedean or the Reciprocating Pumps) originates for the most part as primary production by phytoplankton. Assessing the concentrations, composition and rates of primary production, and variabilities over short time scales, was a major goal of DYNAPROC 2. Phytoplankton were investigated in terms of pigment composition and concentrations, carbon fixation (Marty et al., 2008) as well subjected to microscopic examination (Lasternas et al., 2008). 

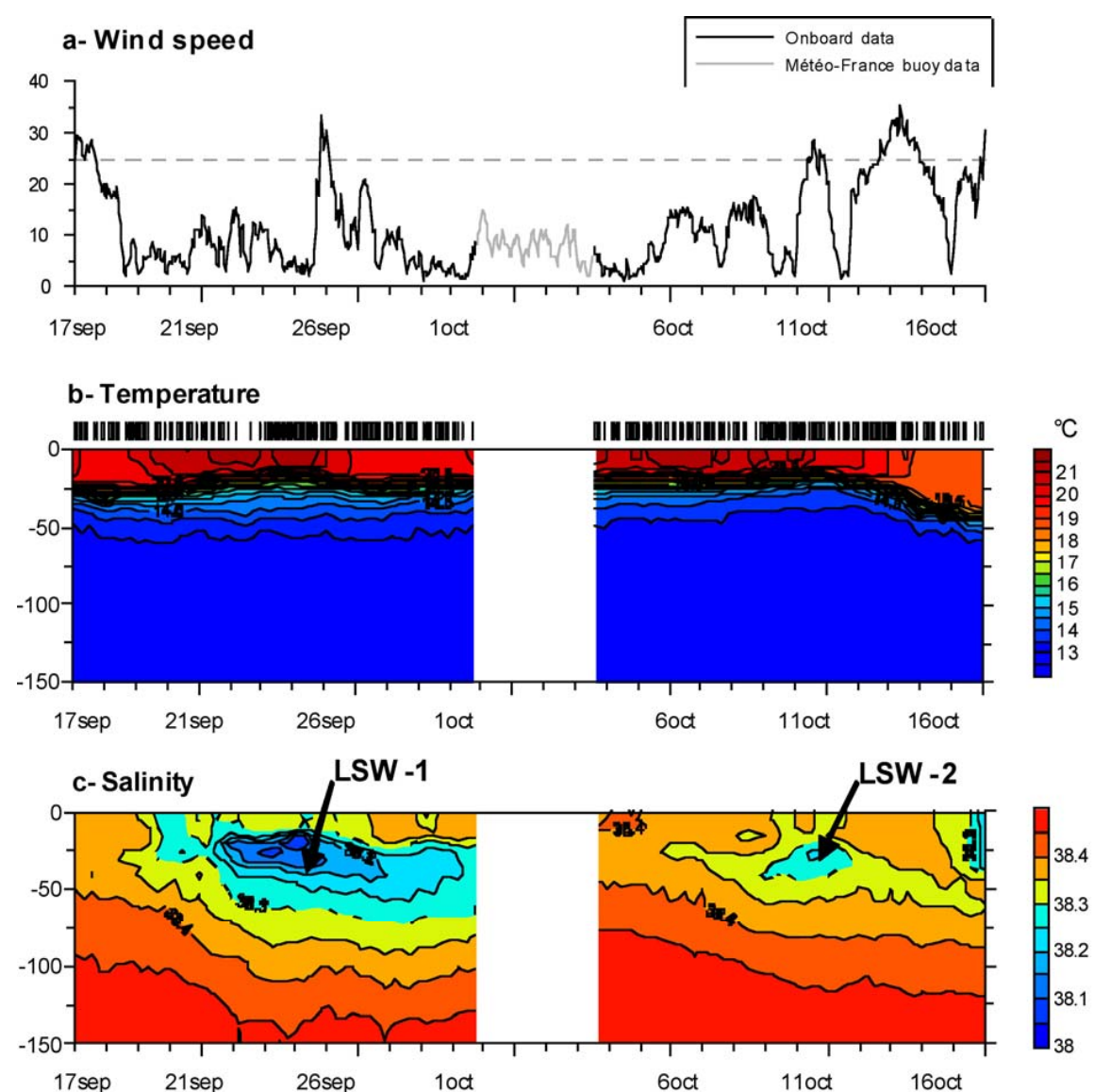

\section{d-Chlorophyll a}

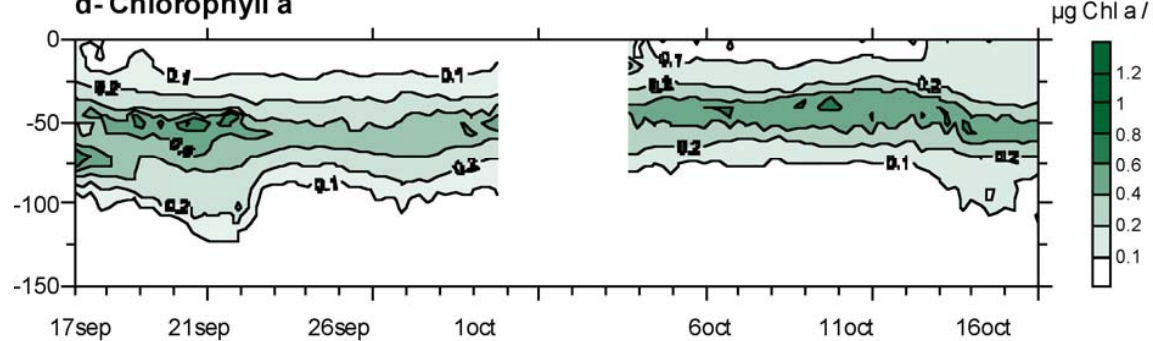

Fig. 3. Time series of meteorological and hydrological data during the DYNAPROC 2 cruise.

Pigment analysis was based on high frequency sampling, every 3 to $6 \mathrm{~h}$ during the 4 cycles of 5 days each. A distinct chlorophyll maximum was present at about $50 \mathrm{~m}$ depth through the sampling (Fig. 3d). Integrating through the first $100 \mathrm{~m}$ of the water column, which encompassed all detectable pigment concentrations and carbon-fixation rates, total chlorophyll ranged widely, from 45 to $17 \mathrm{mg} \mathrm{m}^{-2}$, with high values at the beginning of the cruise. Similarly, primary production ranged from roughly 500 to $200 \mathrm{mg} \mathrm{Cd}^{-1} \mathrm{~m}^{-2}$. Interestingly, there was a quite variable assimilation rate, carbon fixation per unit chlorophyll, similar to that found during the 1995 study of the seasonal transition (Vidussi et al., 2000). Gradients in chlorophyll concentrations and shifts in community composition of the phytoplankton based on pigment-based agreed with microscope-based observations. For example, both pigment data and microscopic examinations showed two distinct occurrences of diatoms, below the chlorophyll maximum depth, first in mid-September, then again in early October (Marty et al., 2008; Lasternas et al., 2008).

The average values of chlorophyll concentration and primary production estimated during DYNAPROC 2 were similar to those estimated for DYNAPROC in 1995 which targeted a seasonal transition (Vidussi et al., 2000). Considering the total ranges found throughout the present study, the variabilities of factors of $2-3$ encountered in bulk concentrations 
and rates (e.g., total chlorophyll $a$ and primary production) exceeded those found in the earlier study which encompassed the transition from spring to summer. Nonetheless some parameters were relatively stable. The number of taxa, for both diatoms alone and dinoflagellates alone varied within a relatively narrow range $( \pm 15 \%)$ while the identity of some dominant taxa shifted considerably, for instance, from centric to pennate diatoms. Overall, the species list of the most common taxa , the core species, was invariant (Lasternas et al., 2008).

\section{Zooplankton}

The zooplankton community is at the center of both the Archimedean Pump, as producers of particulate organic matter, and the Reciprocating Pump in the form of vertically migrating taxa. Species composition, abundances and diversity are detailed in Raybaud et al. (2008a) and Mousseau et al. (2009). Zooplankton biomass was found to vary greatly, between $0.25 \mathrm{~g} \mathrm{~m}^{-2}$ and $3.8 \mathrm{~g} \mathrm{~m}^{-2}$ over the top $200 \mathrm{~m}$ of the water column. The importance of vertical migrators was evident with nighttime biomass values as much as 5 times that of daytime concentrations. The zooplankton community during the night was not only more abundant but also more diverse in terms of species of large copepods (Raybaud et al., 2008a, b). As with the phytoplankton, the identity of the most common taxa was largely invariant throughout the study period. Compared to the previous studies conducted during the spring to summer transition in 1995 (Andersen et al., 2001a, b) a similar range of concentrations of large copepods was found but the species compositions differed. Zooplankton consumption of primary production was estimated indirectly by measuring respiration rates, and then calculating carbon demand, of the dominant forms in shipboard experiments by Mousseau et al. (2009). Little short-term temporal variability in individual respiration rates was detected and, overall, phytoplankton consumption by the zooplankton (mostly copepods) was estimated to be about $10 \%$ of the primary production measured (Mousseau et al., 2009). Thus, zooplankton fecal pellet production, a major contributor to the Archimedean carbon pump, appeared to be a minor carbon pathway, relative to primary production.

\section{The microbial loop}

Bacteria represent the center of the "Rotary" carbon pump, consuming pre-formed organic matter, both dissolved and particulate. Bacterivores and viruses transform bacterial production into either dissolved or particulate organic carbon. In either event most bacterial bcarbon is respired in the surface layer and thus not exported to depth. However, bacteria attached to particles of a size sufficient to sediment represent an exception and would be part of the "Archimedean Pump".
During the DYNAPROC 2 campaign, bacterial biomass was equivalent to about $50 \%$ of that of phytoplankton. Bacterial carbon averaged about $700 \mathrm{mg} \mathrm{C} \mathrm{m}^{-3}$ integrating through the top $150 \mathrm{~m}$ of the water column (Mével et al., 2008) compared to an overall average estimate of phytoplankton biomass of about $1500 \mathrm{mg} \mathrm{C} \mathrm{m}^{-3}$ derived from an average of $30 \mathrm{mg}$ chlorophyll $\mathrm{m}^{-3}$ (Marty et al., 2008) and a chlorophyll to carbon ratio of 50 .

Abundance of bacteria was lower than that found in bloom and post-bloom conditions in this area (Mével et al., 2008; Van Wambeke et al., 2001). Bacterial production, in carbon units averaged about $29 \mathrm{mg} \mathrm{C} \mathrm{m}^{-2} \mathrm{~d}^{-1}$ over the top $150 \mathrm{~m}$ of the water column (Mével et al., 2008), equivalent to $0.2 \mathrm{mg}$ $\mathrm{C} \mathrm{m}^{-3}$, suggesting that bacterial production was very low relative to both total bacterial biomass and phytoplankton production. In contrast, periodically, a large portion (up to about $50 \%$ ) of bacterial activity was associated with particleattached bacteria, as previously observed at the same sampling site under spring conditions (Ghiglione et al., 2007).

Bottom-up factors governing bacterial activity were investigated by Van Wambeke et al. (2009). They documented, using bioassays, a shift from nutrient-limitation by both nitrogen and phosphorous at the beginning of the study period to one of limitation by phosphorus alone following a shoaling of the nutriclines. A rapid response of bacteria, in terms of enzymatic activity and biomass production, to changes in inorganic nutrient concentrations was found by Van Wambeke and co-workers (Van Wambeke et al., 2009).

Comparison of the bacterial communities revealed the existence of distinct communities (Ghiglione et al., 2008). Molecular fingerprinting showed a vertical zonation of bacterial assemblages in three layers, above, in or just below the chlorophyll maximum and deeper, that remained stable during the entire sampling period. Thus, the dramatic shifts in bacterial activity documented by Van Wambeke et al. (2009) were not accompanied by detectable changes in bacterial community composition. Direct gradient multivariate ordination analyses suggested that a complex array of biogeochemical parameters was the driving force structuring the distinct bacterial community compositions in the different portions of the water column. The results of Ghiglione et al. (2008) with regard to the vertical zonation of the bacterial community recall those found by Fuhrman et al. (2006) with regard to temporal patterns.

Ciliate microzooplankton consume primary production in the smaller size-fractions, from 2-20 microns. The portion respired is commonly assumed to be about $50 \%$ (e.g., Dolan and Marrasé, 1995). Thus, carbon consumed by ciliates is largely respired in the surface layer. The activity of ciliates is then part of the Rotary Pump of the microbial loop. Small phytoplankton taxa, based on pigment signatures, overwhelmingly dominated the phytoplankton $(>80 \%$ of the biomass) during DYNAPROC 2 (Marty et al., 2008) suggesting ciliate or other protist grazing to be a potentially very important carbon pathway. 
Ciliates were found in concentrations ranging narrowly, between water column averages of 750 to 1250 cell $^{-1}$ in the top $90 \mathrm{~m}$ of the water column (Lasternas et al., 2008). As most of the ciliate cells were less than $30 \mu \mathrm{m}$, it is likely that their major role was that of "microbial grazers". Compared to the 1995 study of the spring to summer transition (Pérez et al., 2000) with average surface layer concentrations of 3000 ciliates $1^{-1}$, ciliate concentrations were low. Recalling that chlorophyll concentrations and primary production were similar in the 1995 study, a larger portion of the primary production may have been available to the larger metazoan grazers. In the 1995 study, ciliate consumption of primary production was estimated to be about $25 \%$ of primary production (Pérez et al., 2000) in which ciliates were about 2 to 3 times more abundant. Thus, it would appear that during the DYNAPROC 2 study, ciliate microzooplankton would likely have been responsible for consuming roughly $10 \%$ of the primary production estimated. This rough estimate, based simply on relative biomass considerations, agrees well with similar previous estimates for the Western Mediterranean (Dolan et al., 1999). It is worth recalling that that the larger zooplankton, whose phytoplankton consumption rates were estimated indirectly using respiration rates (Mousseau et al., 2009), were estimated to have consumed only about $10 \%$ of total primary production. While it would appear that total grazing pressure was low relative to primary production, some potentially important herbivores were not examined such as heterotrophic dinoflagellates and nanoflagellates.

The community composition of the ciliate component of the food web was assessed in part through an examination of the tintinnid ciliate assemblage. Recalling the patterns found among diatoms and dinoflagellates (Lasternas et al., 2008), the number of species found on each sampling date varied within a narrow range while the identity of the taxa changed (Dolan et al., 2009). However, the identity of the most common "core" species, representing a small part of the species lists but accounting for the overwhelming majority of individuals, was invariant, a pattern also described for the large ( $>500 \mu \mathrm{m}$ ) copepods (Raybaud et al., 2008b).

Overall, in the surface layer, the Rotary Pump, in the form of microbial consumers and re-packagers of carbon, appeared to be a minor carbon pathway compared to rates of primary production. However, it should be noted that possibly important groups (heterotrophic flagellates, mixotrophic flagellates, viruses, etc.) were not examined. Microbial biomass as particle-attached carbon, may have represented a significant input to deep layers periodically, via the Archimedean Pump.

\section{Export fluxes}

POC (particulate organic carbon) fluxes varied by an order of magnitude, in the range $0.03-0.29 \mathrm{mg} \mathrm{C} \mathrm{m}^{-2} \mathrm{~h}^{-1}$ over the month at $200 \mathrm{~m}$ (Marty et al., 2009). The mean export ratio for the cruise was of the order of $2 \%$ of the primary production, which agreed well with export ratios measured at the end of the DYNAPROC 1 cruise in oligotrophic conditions (1-2\%) (Goutx et al., 2000). The most striking evidence in the data was the rapid change in fluxes of the various measured parameters. A day night periodicity was apparent in fluxes, POC fluxes being higher during night time probably linked to diel fluctuation of zooplankton grazing. Indeed, grazing and sedimentation of fecal pellets were the main processes driving POC export, as revealed by biomarkers such as phaeopigments and wax esters (Marty et al., 2009) and fecal pellet counts (Miquel, 2008). Unlike during the DYNAPROC cruise in the spring of 1995 when the wind increased vertical particle flux, in the situation encountered here, the effect of wind events was a decrease of fluxes probably through reduction of zooplankton grazing. But fluxes increased as soon as calm conditions prevailed.

The activity of the carbon pumps can be gauged in qualitative terms by examining the composition and concentrations of dissolved lipid classes. Interestingly, Goutx et al. (2009) found evidence of dissolved organic matter originating in the smallest class of phytoplankton. Furthermore, they documented the appearance of zooplankton wax esters at mid time of the cruise, first in the surface layer and later in deep waters. They related phospholipids in the $400-1000 \mathrm{~m}$ depth layer to bacteria growing on DOM (dissolved organic matter) released from sinking aggregates, which occurred during periods of low wind as noticed for the high POC fluxes.

One of the important findings of the DYNAPROC 2 cruise was documentation of the distinct differences in the temporal variability detected in various components of exported or sedimented matter. For example, fluxes of n-alkanes, sterols and long-chain alkenones varied between consecutive samples $6 \mathrm{~h}$ apart in magnitudes equivalent to seasonal variability, based on material collected below the mixed layer at $200 \mathrm{~m}$ (Méjanelle and Dachs, 2009). Variability between different methodologies was also found as in the larger estimates of sedimentation rates furnished using ${ }^{234} \mathrm{Th}$ and trapped POC fluxes (Schimdt et al., 2009).

\section{Biological effects of short-term physical event - an in- trusion of Low Salinity Water}

Intrusions of low-salinity water mass $(\mathrm{LSW})(<38.3 \mathrm{psu})$ were observed two times during the cruise, unfortunately in coincidence with wind events. Variable possible effects were noted. A microalgae of the genus Scripsiella sp., a form characteristic of coastal rather than open waters, was found at the TSS coinciding with LSW (Lasternas et al., 2008). Among the phytoplankton as whole, the pigment signatures were only slightly affected (Marty et al., 2008). Similarly, among the tintinnids of the ciliate microzooplankton, no effect was noted (Dolan et al., 2009). However, the zooplankton community composition may have shifted based on 
relative abundances of different species of large $(>500 \mu \mathrm{m})$ copepods (Raybaud et al., 2008a). LSW was associated with an increase in total bacterial abundance and production (Mevel et al., 2008). Nonetheless, Marty et al. (2009) concluded that LSW intrusions were probably a minor influence on carbon fluxes and the main variability was probably associated more closely with the effects of wind-driven mixing.

\section{Conclusions}

The studies in this special issue of Biogeosciences Discussions each describe separately the variability encountered in a system which viewed from a distance, for example satellite images obtained a few days apart, could appear to be in a steady-state. Very distinct time-course changes were documented with regard to phytoplankton production (Marty et al., 2008), bacterial activity (Van Wambeke et al., 2009), dissolved organic matter (Goutx et al., 2009) and in both the flux of and composition sedimented particulate matter (Marty et al., 2009; Schmidt et al., 2009; Méjanelle and Dachs, 2009). Remarkably, the least variable characteristic of the system appeared to be the temporal stability of the dominant or core taxa in groups studied in detail across several trophic levels: copepods (Raybaud et al., 2009a, b), phytoplankton (Lasternas et al., 2009), ciliates (Dolan et al., 2009; Raybaud et al., 2009b), and bacteria (Ghiglione et al., 2008). Temporal variability, on the other hand, was notable in the composition of the occasional or rare species among the copepods, phytoplankton and ciliates (Raybaud et al., 2009b).

As in most studies, the DYNAPROC 2 cruise results yielded many more question that it answered. Taking each of the "pumps" in turn it appears that major pathways or processes remain to be quantified. The Archimedian pump of particulate matter, estimated via either POC or ${ }^{234}$ Th fluxes can account for, at most, $5 \%$ of surface layer primary production. The Rotary pump of microbial consumption of primary production and its re-packaging in the surface layer can account for about $10 \%$ of primary production in the form of bacterial carbon demand. The direct grazers of phytoplankton quantified in the DYNAPROC 2 program, ciliate microzooplankton and metazoan zooplankton, the latter including migrators of Reciprocating Pump, likely together account for grazing or processing no more than about $20 \%$ of the primary production based on rough estimates. Obviously then major questions remain, for example, of the importance of organisms not considered (heterotrophic nanoflagellates, dinoflagellates, viruses of phytoplankton, etc.) which consume primary producers.

The wealth of data acquired was destined to be incorporated into a model of the pelagic ecosystem. Tragically, Valerie Andersen, the architect of the cruise program and ecosystem model, passed away before she could accomplish the task she had set for herself of distilling a synthetic view, evaluating the importance of the different carbon pumps. This special issue is dedicated to her memory.

Acknowledgements. This work is part of the PECHE project. Financial support was provided by the INSU of the CNRS through the PROOF and CYBER-LEFE programs (JGOFS-France). Additional support was provided by the ANR-Biodiversity program and the Pôle-Mer PACA through the AQUAPARADOX project. All colleagues from the PECHE team are warmly acknowledged for the work done on board and within the project. A special thanks to the crew of the Thalassa for their efficient aid during the cruise and to Marie-Paule Torre who managed the PECHE project web site and data collection.

Edited by: E. Marañón

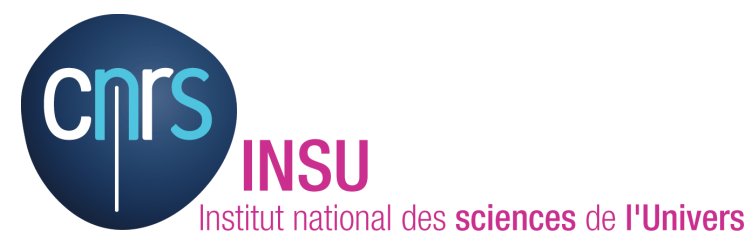

The publication of this article is financed by CNRS-INSU.

\section{References}

Andersen, V. and Prieur, L.: One-month study in the open NW Mediterranean Sea (DYNAPROC experiment, May 1995): Overview of hydrobiogeochemical structures and effects of wind events, Deep-Sea Res. I, 47, 397-422, 2000.

Andersen, V., Nival, P., Caparroy, P., and Gubanova, A.: Zooplankton community during the transition from spring bloom to oligotrophy in the open NW Mediterranean and effects of wind events. 1 - Abundance and specific composition, J. Plankton. Res., 23, 227-242, 2001a.

Andersen, V., Gubanova, A., Nival, P., and Ruellet, T.: Zooplankton community during the transition from spring bloom to oligotrophy in the open NW Mediterranean and effects of wind events. 2 - Vertical distributionsand migrations, J. Plankton. Res., 23, 243-261, 2001b.

Angel, M. V.: Does mesopelagic biology affect the vertical flux?, in: Productivity of the Ocean: Present and Past, edited by: Berger, W. H., Smetacek, V. S., and Wefer, G., John Wiley \& Sons Limited, 155-173, 1989.

Bourguet, N., Goutx, M., Ghiglione, M., Pujo-Pay, M., Mével, G., Momzikoff, A., Mousseau, L., Guigue, C., Garcia, N., Raimbault, P., Pete, R., Oriol, L., and Lefèvre, D.: Lipid biomarkers and bacterial lipase activities as indicators of organic matter and bacterial dynamics in contrasted regimes at the Dyfamed site, NW Mediterranean, Deep-Sea Res. II, in press, 2009.

Banse, K.: Grazing and zooplankton production as key controls of phytoplankton production in the open ocean, Oceanography, 7, 13-20, 1994.

Banse, K.: Zooplankton: Pivotal role in the control of ocean production, ICES J. Mar. Sci., 52, 265-277, 1995.

Christaki, U. and Van Wambeke, F.: Simulated bloom input in topdown manipulated microcosms : comparative effect of zooflag- 
ellates, ciliates and copepods, Aquat. Microb. Ecol. 9, 137-147, 1995.

Christaki, U., Belviso, S., Dolan, J. R., and Corn, M.: Assessment of the role of planktonic copepods and ciliates in the release to solution of DMSP in the N.W. Mediterranean Sea, Mar. Ecol. Prog. Ser., 141, 119-127, 1996.

Christaki, U., Van Wambeke, F., Christou, E. D., Conan, P., and Gaudy, R.: Food web structure variability in the surface layer, at a fixed station influenced by the North Western Mediterranean Current, Hydrobiologia, 321, 145-153, 1996.

Christaki, U., Gaudy, R., and Karabrum, P.: A study of the effects of migratory zooplankton on microbial populations in surface waters of the N.W. Mediterranean, J. Exp. Mar. Biol. Ecol., 225, 173-183, 1998.

Copin-Montégut, C.: Consumption and production on scales of a few days of inorganic carbon, nitrate and oxygen by the planktonic community. Results of continuous measurements at the Dyfamed Station in the northwestern Mediterranean Sea (May 1995), Deep-Sea Res. I, 47, 447-477, 2000.

Dolan, R. and Marrasé, C.: Planktonic ciliate distribution relative to a deep chlorophyll maximum: Catalan Sea, N.W. Mediterranean, June 1993, Deep-Sea Res. I, 42, 1965-1987, 1995.

Dolan, J. R., Viduusi, F., and Claustre, H.: Planktonic ciliates in the Mediterranean Sea: longitudinal trends, Deep-Sea Res. I, 46, 2025-2039, 1999.

Dolan, J. R., Ritchie, M. R., Tunin-Ley, A., and Pizay, M. D.: Dynamics of core and occasional species in the marine plankton: tintinnid ciliates in the north-west Mediterranean Sea, J. Biogeogr., in press, 2009.

Fortier, L., Le Fèvre, J., and Legendre, L.: Export of biogenic carbon to fish and to the deep ocean: the role of large planktonic microphages, J. Plankton. Res., 16, 809-839, 1994.

Frost, B. W. and Franzen, N. C.: Grazing and iron limitation in the control of phytoplankton stock and nutrient concentration: a chemostat analogue of the Pacific equatorial upwelling zone, Mar. Ecol. Prog. Ser., 83, 291-303, 1992.

Fuhrman, J. A., Hewson, I., Schwalbach, M. S., Steele, J. A., Brown, M. V., and Naeem, S.: Annually reoccurring bacterial communities are predictable from ocean conditions, P. Natl. Acad. Sci. USA, 103, 13104-13109, 2006.

Garcia, N., Raimbault, P., Gouze, E., and Sandroni, V.: Fixation de diazote et production primaire en Méditerranée occidentale. Nitrogen fixation and primary production in Western Mediterranean, C. R. Biologies, 329, 742-750, 2006.

Garçon, V. C., Oschlies, A., Doney, S. C., McGillicuddy, D., and Waniek, J.: The role of mesoscale variability on plankton dynamics in the North Atlantic, Deep-Sea Res. II, 48, 2199-2226, 2001.

Ghiglione, J. F., Mevel, G., Pujo-Pay, M., Mousseau, L., Lebaron, P., and Goutx, M.: Diel and seasonal variations in abundance, activity, and community Structure of particle-attached and freeliving bacteria in NW Mediterranean Sea, Microb. Ecol., 54, 217-231, 2007.

Ghiglione, J. F., Palacios, C., Marty, J. C., Mével, G., Labrune, C., Conan, P., Pujo-Pay, M., Garcia, N., and Goutx, M.: Role of environmental factors for the vertical distribution $(0-1000 \mathrm{~m})$ of marine bacterial communities in the NW Mediterranean Sea, Biogeosciences, 5, 1751-1764, 2008, http://www.biogeosciences.net/5/1751/2008/.
Goutx, M., Guigue, C., Aritio, D., Ghiglione, J., Pujo-Pay, M., and Andersen, V.: Short term variability of dissolved lipid classes during summer to autumn transition in the Ligurian sea (NW Mediterranean), Biogeosciences Discuss., 6, 27-69, 2009, http://www.biogeosciences-discuss.net/6/27/2009/.

Goutx, M., Momzikoff, A., Striby, L., Andersen, V., Marty, J.-C., and Vescovali, I.: High frequency fluxes of labile compounds in the central Ligurian Sea, northwestern Mediterranean, Deep-Sea Res. I, 47, 533-556, 2000.

Lasternas, S., Tunin-Ley, A., Ibañez, F., Andersen, V., Pizay, M.-D., and Lem 'ee, R.: Dynamics of microphytoplankton abundance and diversity in NW Mediterranean Sea during late summer condition (DYNAPROC 2 cruise; SeptemberOctober 2004), Biogeosciences Discuss., 5, 5163-5202, 2008,

http://www.biogeosciences-discuss.net/5/5163/2008/.

Longhurst, A. R.: Role of the marine biosphere in the global carbon cycle, Limnol. Oceanogr., 36, 1057-1526, 1991.

Marine Zooplankton Colloquium 2: Future marine zooplankton research - a perspective, Mar. Ecol. Prog. Ser., 222, 297-308, 2001.

Marty, J. C.: The DYFAMED time-series program (FrenchJGOFS), Deep-Sea Res. II, 49,1963-1964, 2002.

Marty, J. C., Chiavérini, J., Pizay, M. D., and Avril, B.: Seasonal and interannual dynamics of nutrients and phytoplankton pigments in the Western Mediterranean Sea at the DYFAMED timeseries station (1991-1999), Deep Sea Res. II, 49, 1965-1986, 2002.

Marty, J. C., Garcia, N., and Raimbault, P.: Phytoplankton dynamics and primary production under late summer conditions in the NW Mediterranean Sea, Deep-sea Res. I, 55, 1131-1149, 2008.

Marty, J. C., Goutx, M., Guigue, C., Leblond, N., and Raimbault, P.: Short-term changes in particulate fluxes measured by drifting sediment traps during end summer oligotrophic regime in the NW Mediterranean Sea, Biogeosciences Discuss., 6, 575-606, 2009, http://www.biogeosciences-discuss.net/6/575/2009/.

Méjanelle, L. and Dachs, J.: Short scale $(6 \mathrm{~h})$ temporal variation of sinking fluxes of planktonic and terrigeneous lipids at $200 \mathrm{~m}$ in the NW Mediterranean Sea, Biogeosciences Discuss., 6, 12291265, 2009, http://www.biogeosciences-discuss.net/6/1229/2009/.

Mével, G., Vernet, M., Goutx, M., and Ghiglione, J. F.: Seasonal to hour variation scales in abundance and production of total and particle-attached bacteria in the open NW Mediterranean Sea (0$1000 \mathrm{~m})$, Biogeosciences, 5, 1573-1586, 2008, http://www.biogeosciences.net/5/1573/2008/.

Miquel, J. C.: Downward POC flux through the mesopelagic zone and the contribution of zooplankton. IMBER-IMBiZO, Integrating Biogeochemistry and Ecosystems in a Changing Ocean, Miami, FL, USA, 9-13 November, 2008.

Mousseau, L., Lefevre, D., Narcy, F., Nival, P., and Andersen, V.: A one-month study of the zooplankton community at a fixed station in the Ligurian Sea: the potential impact of the species composition on the mineralization of organic matter, Biogeosciences Discuss., 6, 995-1019, 2009, http://www.biogeosciences-discuss.net/6/995/2009/.

Pérez, M. T., Dolan, J. R., and Fukai, E.: Planktonic oligotrich ciliates in the N. W. Mediterranean: growth rates and consumption by copepods, Mar. Ecol. Prog. Ser., 155, 89-101, 1997.

Pérez, M. T., Dolan, J. R., Vidussi, F., and Fukai, E.: Diel vertical 
distribution of planktonic ciliates within the surface layer of the NW Mediterranean (May 1995), Deep-Sea Res. I, 47, 479-503, 2000.

Raybaud, V., Nival, P., Mousseau, L., Gubanova, A., Altukhov, D., Khvorov, S., Ibañez, F., and Andersen, V.: Short term changes in zooplankton community during the summer-autumn transition in the open NW Mediterranean Sea: species composition, abundance and diversity, Biogeosciences, 5, 1765-1782, 2008, http://www.biogeosciences.net/5/1765/2008/.

Raybaud, V., Tunin-Ley, A., Ritchie, M. E., and Dolan, J. R.: Similar patterns of community organization characterize distinct groups of different trophic levels in the plankton of the NW Mediterranean Sea, Biogeosciences Discuss., 5, 4897-4917, 2008, http://www.biogeosciences-discuss.net/5/4897/2008/.

Schmidt, S., Goutx, M., Raimbault, P., Garcia, N., Guibert, P., and Andersen, V.: Th measured particle export from surface waters in north-western Mediterranean: comparison of spring and autumn periods, Biogeosciences Discuss., 6, 143-161, 2009, http://www.biogeosciences-discuss.net/6/143/2009/.

Steele, J. H. and Henderson, E. W.: The role of predation in plankton models, J. Plankton. Res., 14, 157-172, 1992.

Stemmann, L., Picheral, M., and Gorsky, G.: Diel changes in the vertical distribution of suspended particulate matter in the NW Mediterranean Sea investigated with the Underwater Video Profiler, Deep-Sea Res. I, 47, 505-531, 2002.
Van Wambeke, F., Christaki, U., and Gaudy, R.: Carbon fluxes from the microbial food web to mesozooplankton. An approach in the surface layer of a pelagic area (NW Mediterranean Sea, Oceanol. Acta, 19, 57-66, 1996.

Van Wambeke, F., Goutx, M., Striby, L., Sempéré, R., and Vidussi, F.: Bacterial dynamics during the transition from spring bloom to oligotrophy in the northwestern Mediterranean Sea: relationships with particulate detritus and dissolved organic matter, Mar. Ecol. Prog. Ser, 212, 89-105, 2001.

Van Wambeke, F., Ghiglione, J-F., Nedoma, J., Mével, G., and Raimbault, P.: Short scale variations in nutrients, ectoenzymatic activities and bottom-up effects on bacterial production and community structure during late summer-autumn transition in the open NW Mediterranean Sea, Biogeosciences Discuss., 6, 687727, 2009, http://www.biogeosciences-discuss.net/6/687/2009/.

Verity, P. G. and Smetacek, V.: Organism life cycles, predation, and the structure of marine pelagic ecosystems, Mar. Ecol. Prog. Ser., 130, 277-293, 1996.

Vidussi, F., Marty, J.-C., and Chiavérini, J.: Phytoplankton pigment variations during the transition from spring bloom to oligotrophy in the Mediterranean Sea, Deep-Sea Res. I, 47, 423-445, 2000. 